
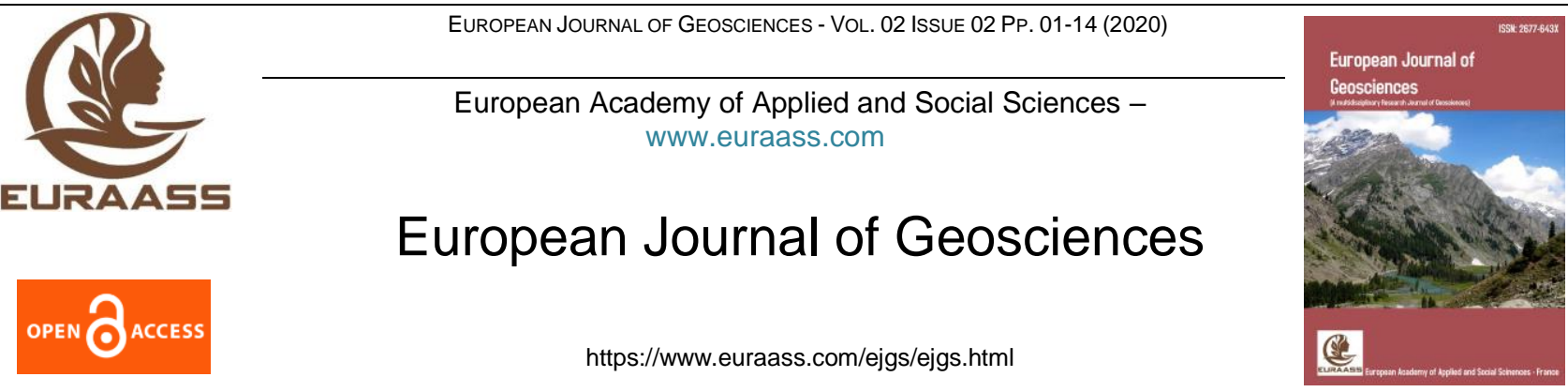

Research Article

\title{
Study atmospheric pollution to develop a process for calculating the isolation safe distance for livestock activities: Applied in Ho Chi Minh City
}

\section{Thoai Tam Nguyen ${ }^{\mathrm{a}}$, Hoang Ngoc Khue $\mathrm{Vu}^{\mathrm{a}}$, Thi Thu Thuy Nguyen ${ }^{a}$, Thi Thuy Hang Nguyen ${ }^{a}$, Quoc Bang Ho ${ }^{a *}$}

${ }^{a}$ Institute of Environment \& Resources, Vietnam National University, Ho Chi Minh City, Vietnam.

Received: 10 September 2019 / Revised: 12 May 2020 / Accepted: 13 July 2020

\begin{abstract}
Ho Chi Minh City (HCMC) is the largest city in Vietnam, with the highest economic growth rate and the most populous density in the country. By the year 2019, HCMC currently has 8.99 million people with 24 districts. Ho Chi Minh city has robust industrial and service development; therefore, this city focuses on developing large-scale livestock facilities with a large number of pigs and limiting small livestock facilities. According to statistic data, HCMC has a total of 275,000 pigs in 2019 . These livestock facilities are mainly built in $\mathrm{Cu}$ Chi, Hoc Mon, Binh Chanh, Can Gio, and Nha Be districts. These livestock facilities in HCMC have inefficient waste treatment systems located interleaved with residential areas. So that, environmental issues are also a big challenge for the city's government because of the great influence of odor on the surrounding environment causing by the wind direction. The main purposes of this study are (i) calculation of odor emissions from livestock facilities, (ii) simulation of the odor from livestock facilities, and (iii) development of the safe distance of odor for livestock facilities in HCMC. The study results show that $230 \mathrm{~m}$ and $650 \mathrm{~m}$ is the minimum distance from the livestock facility with capacity from over 500 to 1,000 pigs and over 1,000 pigs to the residential area, respectively. The procedure for calculating the odor isolation distance developing in this study could apply for other livestock facilities in other provinces, cities.
\end{abstract}

Keywords: Livestock, Atmospheric pollution, TAPM model, AERMOD model, Ho Chi Minh city.

(c) Euraass 2020. All rights reserved.

\section{INTRODUCTION}

As the largest city in Vietnam, HCMC has a high growth rate of economics and service, culture and society, science and technology. The gross regional domestic product (GRDP) growth rate of HCMC in 2018 reached 8.3\%. In which, the average growth rate in 2017 of service, industry - construction, and agriculture was 7.38\%, 7.17\%, and 5.93\%, respectively (Committee, 2019). Along

* Corresponding author: Email: bangquoc@yahoo.com (Ho Q.B.).

Available online: $30^{\text {th }}$ July 2020

DOI: Yet to add

Journal reference: Eur. J. Geosc. 2020, 02(02), 01 - 14.

ISSN-E: 2677-643X.

(c) European Academy of Applied and Social Sciences. Euraass - 2020. All rights reserved.

Cite as: Nguyen, T.T., Vu, H.N.K., Thuy, N.T.T., Nguyen, T.T.H., Ho, Q.B. (2020) Study atmospheric pollution to develop a process for calculating the isolation safe distance for livestock activities: Applied in Ho Chi Minh City. Eur. J. Geosc. 02(02), $01-14$. 
with the highest economic development, HCMC is facing a serious environmental problem, especially in air pollution. The pollutants emit from factories, industrial zone using old technology or from transportation causing by high traffic density, expired transport means, and the undeveloped road network. The agricultural sector, especially the livestock activities in the HCMC, has also caused serious environmental problems such as odor pollution because these livestock facilities are located alternately in the residential area and do not have a hygienic animal waste treatment system.

According to data from the general statistics office, the total pigs in Vietnam are 28,151,948 in 2018 increasing $2.7 \%$ over the same period in 2017. In which, the total number of pigs in HCMC are 290,152 raised at 1,145 livestock facilities with a scale of 50 or more pigs. On 17 February 2020, HCMC People's Committee issued decision No. 545/QD-UBND about on Restructuring livestock activities in HCMC stage 2020-2025. According to this decision, the target by 2025 is maintaining a total of 200,000 pigs with an average capacity of 200 heads/livestock facility, focusing on the districts of Cu Chi, Hoc Mon, Binh Chanh, Can Gio and Nha Be.

In livestock activities, odor arises primarily from the digestion of food and manure. $\mathrm{H}_{2} \mathrm{~S}, \mathrm{CH}_{3} \mathrm{SH}$, and $\mathrm{NH}_{3}$ from livestock activities are one of the substances that cause odor pollution in the ambient air. Nowadays, most of these livestock facilities in HCMC are in Binh Chanh, Hoc Mon, $\mathrm{Cu}$ Chi district and integrating with residential areas, but most of them do not have the treatment system from livestock activities. Therefore, odor from these livestock facilities is a challenge for local environmental management agencies. The Vietnam Livestock Department has issued Decision No. 397/QĐ-CN-MTCN about Environmental protection guidance plans in concentrated livestock activities. This decision clearly states that: for livestock activities, it must be built separately, away from hospitals, schools, markets, offices, crowded residential areas, inter-provincial and inter-district roads at least $100 \mathrm{~m}$. This decision only regulates the minimum distance but not regulate the number of pigs in livestock facilities. It is well known that the emission load from livestock facilities with 100 pigs is very different livestock facilities with 1,000 pigs. Moreover, the safe distance about odor of each livestock facility depends on not only the number of pigs but also wind speed, livestock facilities location, etc. In Vietnam, there have been studies to evaluate and propose solutions to reduce the pollution of wastewater and solid waste generated from livestock activities (Truong Thanh Canh 1998, Canh, 2010, Hoa, 2017, Ho Minh Dung, 2019). However, no study on odor simulation to build a safe distance procedure for livestock activities has not been found in the literature. Therefore, this study was conducted to aims at (i) Calculation of $\mathrm{H}_{2} \mathrm{~S}, \mathrm{CH}_{3} \mathrm{SH}, \mathrm{NH}_{3}$ emissions from livestock facilities; (ii) simulation of $\mathrm{H}_{2} \mathrm{~S}, \mathrm{CH}_{3} \mathrm{SH}, \mathrm{NH}_{3}$ concentration from livestock activities by TAPM - AERMOD system model; (iii) and development of the odor isolation distance for livestock facilities.

\section{MATERIALS AND METHODS}

\subsection{Emission calculation}

Nowadays, there has been a lot of methods to calculate emissions inventory over the world. However, each method depends on the conducted time, financial capacity, and human resources. For example, for the point source, data from continuous emissions monitoring are required. This is the best method for emission inventory; however, due to limited human and financial resources, it is difficult to implement in Vietnam in particular and other developing countries in general. Meanwhile, other inventory methods require fewer input data. Therefore, the methods may vary depending on the data available. A reasonable approach to calculate for livestock facilities, emission factor approach, was used in this study.

With livestock facilities, US EPA's emissions inventory guidelines - AP 42, EMEP / EEA air pollutant emission inventory guidebook-2019 were used to calculate the emission. The emission factor in this study is referenced from the research results of Ho Minh Dung, 2018.

The emission from livestock activities is calculated by the formula:

$$
E=A R \times E F \times(1-E R / 100)
$$


Where: E: Emission rate (g/day); EF: Emission factor (g/pig.day); AR: Activities rate (the number of pig in livestock facilities), (pig); ER: emission reduction efficiency $(\%)$.

Table 1: $\mathrm{H}_{2} \mathrm{~S}, \mathrm{NH}_{3}, \mathrm{CH}_{3} \mathrm{SH}$ emission factor for livestock activities (g/pig.day).

\begin{tabular}{cccc}
\hline Type & $\mathrm{H}_{2} \mathrm{~S}$ & $\mathrm{NH}_{3}$ & $\mathrm{CH}_{3} \mathrm{SH}$ \\
\hline $\mathrm{Pig}$ & 0.149 & 0.800 & 0.086 \\
\hline
\end{tabular}

Source: (Kenneth D. Casey 2006, Ki Youn Kim 2007, Wen Xu 2014)

In addition, 12 livestock facilities were investigated to calculate and simulate the odor emission based on Taro Yamane's formula with a $97 \%$ confidence level:

$$
n=\frac{N}{\left(1+N \times e^{2}\right)}
$$

Where: $\mathrm{n}$ : sample size; $\mathrm{N}$ : total livestock facilities from over 50 pigs/livestock facilities; e: is the level of precision.

Based on the actual statistical data five types of livestock facilities were conducted and the number of each type presented in Table 2. In each facility, the coordinates, the number of pigs, the odor treatment system, and the distance from this facility to the surrounding area were collected.

Table 2: The livestock facilities capacity type and number of survey.

\begin{tabular}{|c|c|c|c|c|c|}
\hline $\mathbf{N}^{0}$ & Capacity livestock facility & $\begin{array}{l}\text { Total } \\
\text { of pig }\end{array}$ & $\begin{array}{c}\text { Total } \\
\text { livestock facilities }\end{array}$ & $\begin{array}{l}\text { Number } \\
\text { survey }\end{array}$ & of \\
\hline 1. & From 50 to 200 pigs & & & 3 & \\
\hline 2. & Over 200 to 500 pigs & & & 3 & \\
\hline 3. & Over 500 to 1,000 pigs & $\begin{array}{l}186.20 \\
5\end{array}$ & 1.145 & 3 & \\
\hline 4. & Over 1,000 to 10,000 pigs & & & 2 & \\
\hline 5. & Over 10,000 pigs & & & 1 & \\
\hline
\end{tabular}

Source: General Statistics Office 2019.

\subsection{TAPM model}

The TAPM model, a three-dimensional prognostic meteorological and air pollution model, was developed by the Commonwealth Scientific and Research Organisation (CSIRO) in Australia for use in air quality studies on a local, regional or inter-regional scale (Hurley, 2008). Recently, an enhanced version of TAPM called TAPM-CTM was also developed by CSIRO to include options to use the Lurman, Carter, and Coyner (LCC) or the Carbon Bond 4 and 5 (CB4, CB5) photochemical mechanisms (Cope, 2009). The original TAPM only has the simplified Generic Reaction Set (GRS) photochemical component, which was based on smog chamber studies. The meteorological component of TAPM is an incompressible, optionally non-hydrostatic, equation model with a terrain-following vertical coordinate for three-dimensional simulations. Cloud/rain/snow micro-physical processes, turbulence closure, urban/vegetative canopy and soil, and radiative fluxes are modeled and parameterized in equations. The model solution for winds, potential virtual temperature, and specific humidity, is weakly nudged with a 24 -hour e-folding time towards the synoptic-scale input values of these variables.

Global reanalysis meteorological host data such as ERA-interim or NCEP (National Centers for Environmental Prediction) can be adapted to be used with TAPM. TAPM model simulated by nested grid cells, in this study, there are four domains from D1 (biggest) to 
D4 (smallest) were selected to simulate. The innermost domain (D4) is this study area with dimensions of $100 \mathrm{~km} \times 100 \mathrm{~km}$ and grid resolution of 40 cells $\times 40$ cells, the dimension of one cell is $2.5 \mathrm{~km} \times 2.5 \mathrm{~km}$.

\subsection{AERMOD model}

The AERMOD Model - The AMS/EPA Regulatory Model (AERMOD) is designed to support the US Environmental Protection Agency (EPA) management program. The model consists of three components: AERMOD (AERMIC Scattering Model), AERMOD (AERMOD Terrain Tool), and AERMOD (AERMOD Meteorological Tool). Since 1991, the AERMOD model has been developed by the Meteorological Agency and the US Environmental Protection Agency. A team of scientists (AERMIC) has teamed up to build the AERMOD model. AERMOD was officially used on December 9, 2005 after 14 years of research and development.

The AERMOD model includes a range of options for simulating air quality impacted by waste streams, building common options for many applications. AERMET manages meteorological data on the surface and on different levels, allowing calculation of atmospheric characteristics according to the Monin - Obukhov model. The meteor file consists of the following two types of files: surface met data file (* .sam) is the observed data recorded per hour including the following data: wind direction, wind speed, humidity, atmospheric pressure, precipitation, cloud cover, solar radiation; The upper air met data file ( ${ }^{*}$.ua) is the data that is monitored twice a day at 0 GMT (7:00 LST) and 12 GMT (19:00 LST) including altitude disturbance data. AERMAP is integrated with models related to the topography, the effect of smoke trail when exposed to hills. AERMET combines data from WebGIS to create terrain files for the model. From the above data, AERMOD will produce simulation results in the form of 2-dimensional, three-dimensional images and exported through Google Earth, making it easy for users to see the effects of emissions to the survey area (Lakesenvironmental, 2013).

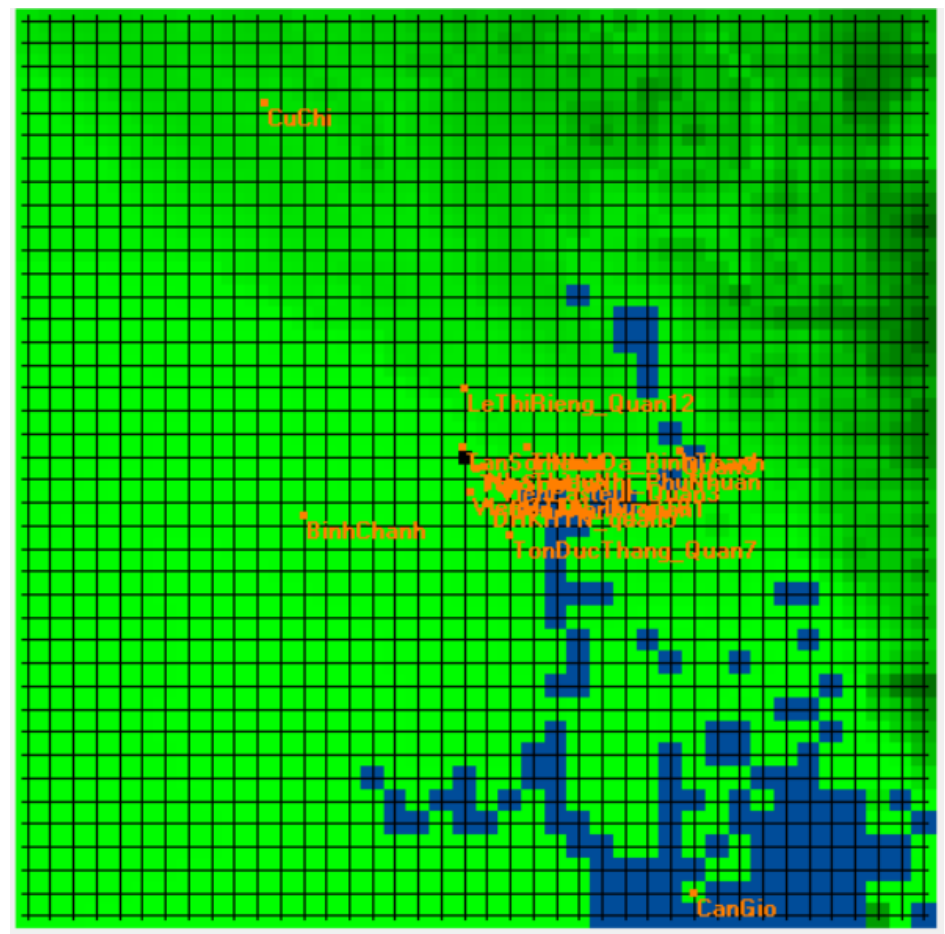

Figure 1: The D4 domain used in TAPM model. 


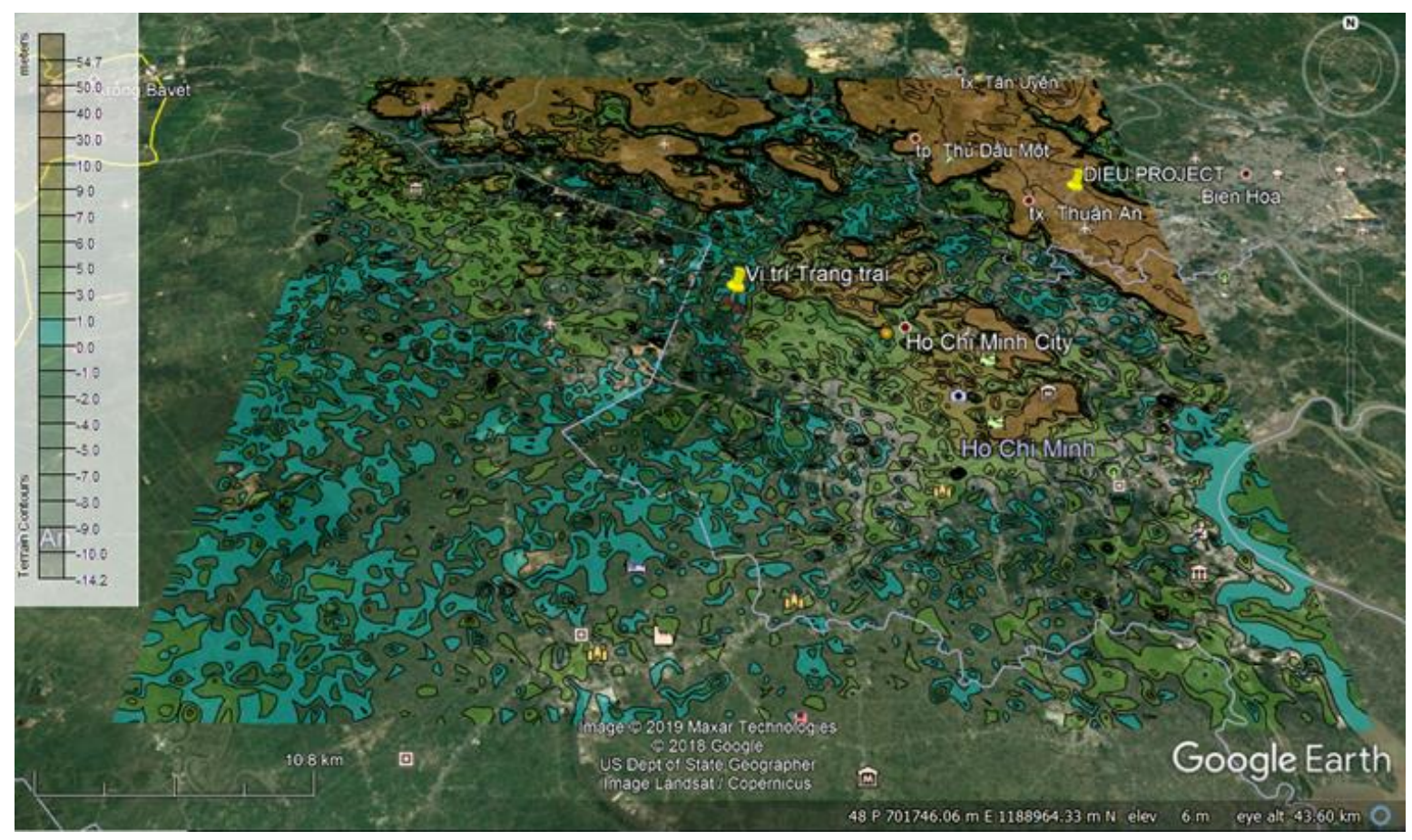

Figure 2: Topographic map of the simulation area in this study.

\subsection{Calibration and testing TAMP - AERMOD model}

Meteorological data used to calibrate and test the TAMP model was collected from Tan Son Hoa meteorological station for April 2017. Similarly, input meteorological data for the TAPM model were also downloaded at the same time from CSIRO website. This is a global meteorological monitor provided by the Australian Meteorological Agency.

After the TAMP model was calibrated with the most suitable parameters, the TAPM model would be run for the study area., Results from the TAPM model would be used as input data for the AERMOD model. Simulation results also would be calibrated with the observed air quality monitoring data at Dong Hiep livestock facility. These following statistical formulas would be used to evaluate the accuracy of the model (MAGE, and $R^{2}$ ) (Ho Quoc Bang, 2016, Ho Minh Dung, 2019)

where: Pi: Simulation data, Oi: Monitoring data, N (n) quantity of data.

$$
\begin{gathered}
M A G E=\frac{1}{n} \sum_{i=1}^{n}\left(\frac{|P i-O i|}{O i} \times 100\right) \\
R=\frac{\sum(P i-\bar{P} \iota)(O i-\overline{O \iota})}{\sqrt{\sum(P i-\bar{P} \iota)^{2} \sum(O i-\overline{O \imath})^{2}}}
\end{gathered}
$$




\section{RESULTS AND DISCUSSION}

\subsection{Odor emission from livestock facility}

Odor emission results for each livestock facility are shown in Table 3. This results will be used as input data for AERMOD dispersion model to simulate odor dispersion and calculate odor isolation distance over HCMC. Table 3 shows that oder emissions $\left(\mathrm{NH}_{3}, \mathrm{H}_{2} \mathrm{~S}\right.$ and $\left.\mathrm{CH}_{3} \mathrm{SH}\right)$ change very much depending on the size of livestock facilities in HCMC. Specifically, TT12 has 18.000 pigs, but emission rate lower than other livestock facilities with capacity from 200 to 3,000 pigs because the area of TT12 is $250,000 \mathrm{~m}^{2}$. TT4 with 231 pigs and $173 \mathrm{~m}^{2}$ of area, this livestock facility with highest odor emission in this study. Compared to the study of Ho Minh Dung (2018) in Chau Duc district, Ba Ria Vung Tau province, $\mathrm{CH}_{3} \mathrm{SH}$ emission rate in this study higher than $10 \%$ Ho Minh Dung's study.

\subsection{Calibration and testing model}

\subsubsection{TAPM model}

Simulation result from TAPM model was compared with monitoring data from Tan Son Hoa station in April 2017. The testing result is shown in Figure 3. The calibration and testing result for temperature and wind speed from the TAPM model showed that the simulation values were quite good compared to the monitoring results. The strong correlation $\left(R^{2}=0.82\right)$ between the observed and predicted data of temperature was found (Figure 3). In addition, the average, standard deviation, highest, and lowest value of temperature were almost the same with the error of about $\pm 1^{\circ} \mathrm{C}$. The wind speed simulation results show that the simulation value is quite good compared to the monitoring results, the smallest wind speed in study area close to zero, the monthly average wind speed is about $2 \mathrm{~m} / \mathrm{s}$. Standard deviation is about $1 \mathrm{~m} / \mathrm{s}$ for simulation and monitoring.

Table 3: Odor emission results.

\begin{tabular}{|c|c|c|c|c|c|c|c|}
\hline \multirow[b]{2}{*}{$\mathbf{N}^{\circ}$} & \multirow[b]{2}{*}{ Symbol } & \multirow{2}{*}{$\begin{array}{l}\text { Livestock } \\
\text { capacity }\end{array}$} & \multirow[b]{2}{*}{$\begin{array}{l}\text { Area } \\
\left(\mathrm{m}^{2}\right)\end{array}$} & \multirow{2}{*}{$\begin{array}{c}\text { Number of } \\
\text { pig } \\
\text { (pig) }\end{array}$} & \multicolumn{3}{|c|}{ Odor Emission } \\
\hline & & & & & $\begin{array}{c}\mathrm{NH}_{3} \\
\left(\mathrm{~g} / \mathrm{day} / \mathrm{m}^{2}\right)\end{array}$ & $\begin{array}{c}\mathrm{H}_{2} \mathrm{~S} \\
\left(\mathrm{~g} / \text { day } / \mathrm{m}^{2}\right)\end{array}$ & $\begin{array}{c}\mathrm{CH}_{3} \mathrm{SH} \\
\left(\mathrm{g} / \text { day } / \mathrm{m}^{2}\right)\end{array}$ \\
\hline 1. & TT1 & \multirow{3}{*}{$\begin{array}{c}\text { From } 50 \text { to } 200 \\
\text { pigs }\end{array}$} & 4,500 & 155 & 0.028 & 0.005 & 0.003 \\
\hline 2. & TT2 & & 113 & 100 & 0.708 & 0.132 & 0.076 \\
\hline 3. & TT3 & & 137 & 103 & 0.601 & 0.112 & 0.065 \\
\hline 4. & TT4 & \multirow{3}{*}{$\begin{array}{c}\text { Over } 200 \text { to } 500 \\
\text { pigs }\end{array}$} & 173 & 231 & 1.068 & 0.199 & 0.115 \\
\hline 5. & TT5 & & 252 & 210 & 0.667 & 0.124 & 0.072 \\
\hline 6. & TT6 & & 200 & 200 & 0.800 & 0.149 & 0.086 \\
\hline 7. & TT7 & \multirow{3}{*}{$\begin{array}{l}\text { Over } 500 \text { to } \\
1,000 \text { pigs }\end{array}$} & 1,982 & 991 & 0.400 & 0.075 & 0.043 \\
\hline 8. & TT8 & & 1,680 & 1,000 & 0.533 & 0,099 & 0.057 \\
\hline 9. & TT9 & & 1,035 & 1,150 & 0.889 & 0.166 & 0.096 \\
\hline 10. & TT10 & \multirow{2}{*}{$\begin{array}{l}\text { Over } 1,000 \text { to } \\
10,000 \text { pigs }\end{array}$} & 2,206 & 2,251 & 0.816 & 0.152 & 0.088 \\
\hline 11. & TT11 & & 3,840 & 2,954 & $0, .615$ & 0.115 & 0.066 \\
\hline 12. & TT12 & Over 10,000 pigs & 250,000 & 18,000 & 0.058 & 0.011 & 0.006 \\
\hline
\end{tabular}




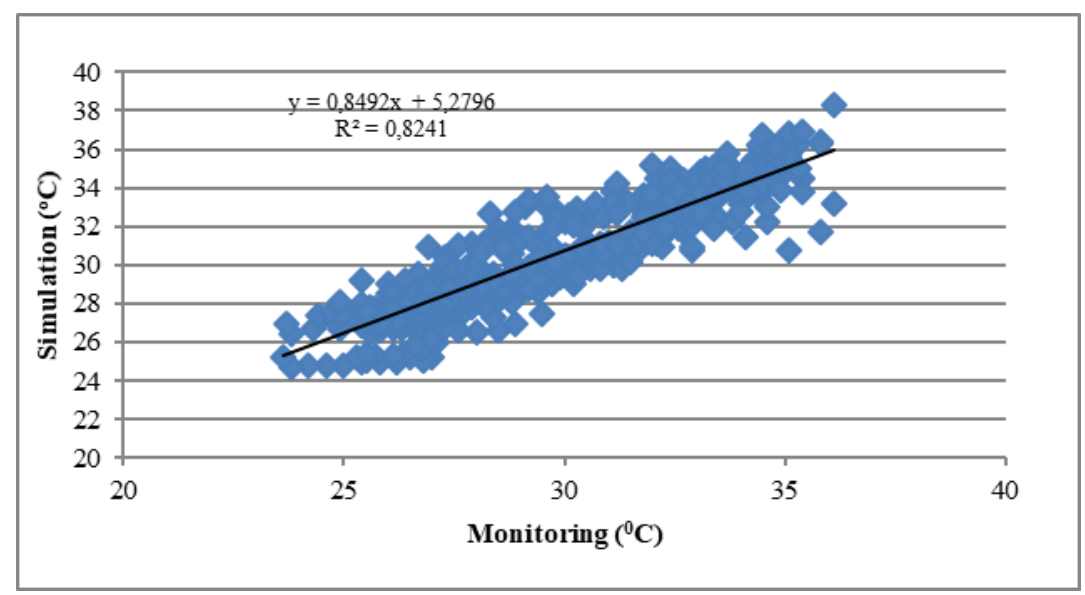

Figure 3: Temperature correlation between simulation value using TAPM model and monitoring at Tan Son Hoa station.

\subsubsection{AERMOD model}

The results of AERMOD model were compared with monitoring data of Dong Hiep livestock facility, Cu Chi district. As all values of MAPE for $\mathrm{H}_{2} \mathrm{~S}, \mathrm{CH}_{3} \mathrm{SH}, \mathrm{NH}_{3}$ were within the allowable range $\pm 15 \%$, so, AERMOD model is suitable to simulate the odor dispersion of the study area.

Table 4. Testing result of AERMOD model in the study area.

\begin{tabular}{cccccc}
\hline \multirow{2}{*}{ Parameter } & Livestock facility & \multicolumn{3}{c}{ MAGE (\%) } \\
\cline { 3 - 5 } & & $\mathrm{NH}_{3}$ & $\mathbf{H}_{2} \mathbf{S}$ & $\mathbf{C H}_{3} \mathbf{S H}$ & Requirement \\
\cline { 3 - 5 } MAGE & TT12 & $12.30 \%$ & $11.10 \%$ & $10.00 \%$ & $\leq \pm 15 \%$ \\
\hline
\end{tabular}

\subsection{Odor simulation results}

3.3.1 Livestock facility with capacity from 50 to 200 pigs and over 200 to 500 pigs.

Odor simulated results for livestock facility with capacity from 50 to 200 pigs are shown in Figure 4 . Generally, the concentration of $\mathrm{H}_{2} \mathrm{~S}, \mathrm{CH}_{3} \mathrm{SH}, \mathrm{NH}_{3}$ were lower than the permitted levels according to QCVN 06:2009/BTNMT. The highest values for 1 hour of $\mathrm{H}_{2} \mathrm{~S}$, $\mathrm{CH}_{3} \mathrm{SH}, \mathrm{NH}_{3}$ reached $12.2 \mu \mathrm{g} / \mathrm{m}^{3}, 7.04 \mu \mathrm{g} / \mathrm{m}^{3}$ và $65.5 \mu \mathrm{g} / \mathrm{m}^{3}$, respectively. 


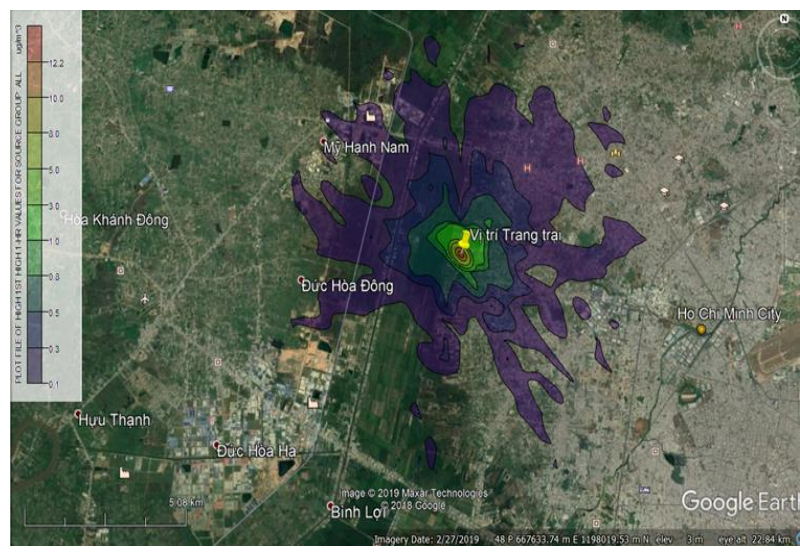

(l)

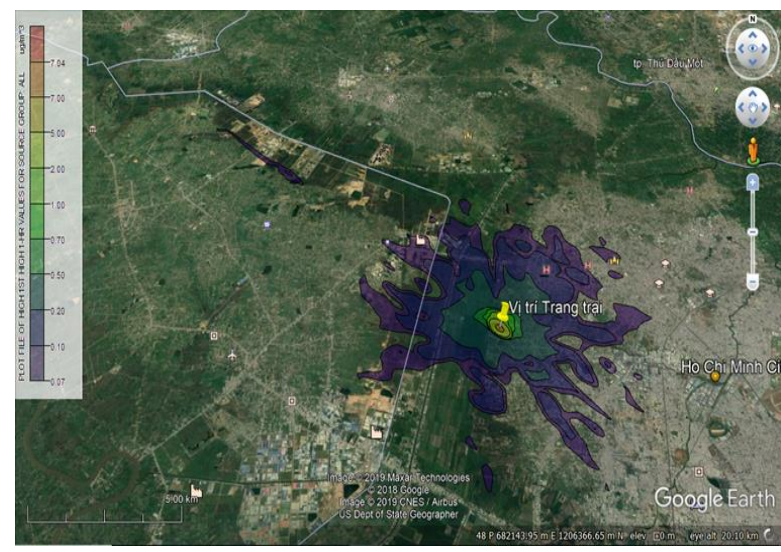

(II)

Figure 4: Simulated result for $\mathrm{H}_{2} \mathrm{~S}(\mathrm{I}), \mathrm{CH}_{3} \mathrm{SH}$ (II), concentrations $\left(\mu \mathrm{g} / \mathrm{m}^{3}\right)$ map of the highest mean 1 hour for livestock facility with capacity from 50 to 200 pigs.

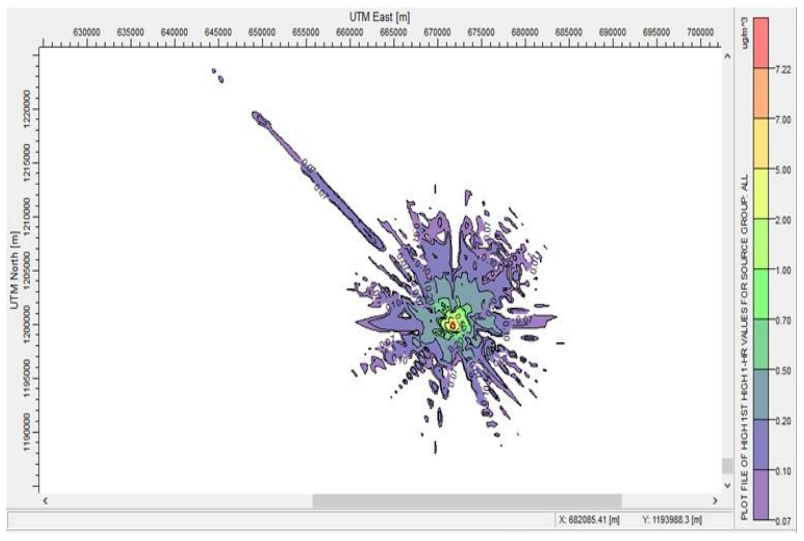

(I)

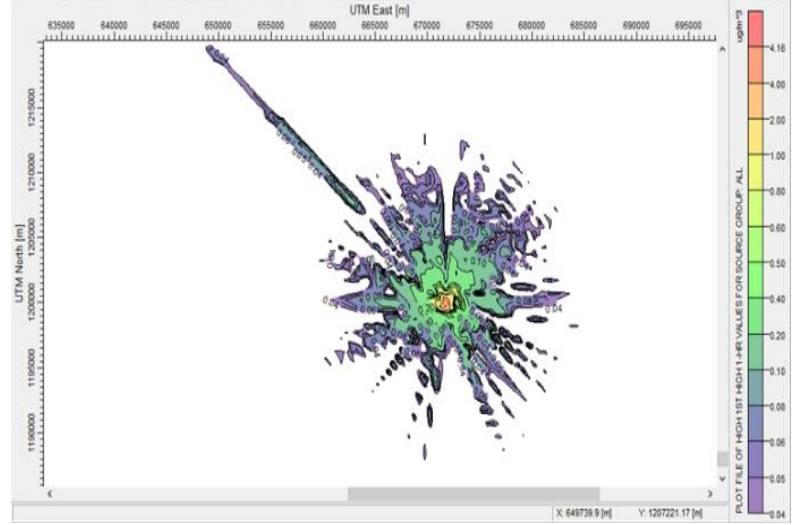

(II)

Figure 5: Simulated result for $\mathrm{H}_{2} \mathrm{~S}(\mathrm{I}), \mathrm{CH}_{3} \mathrm{SH}$ (II) in concentrations $\left(\mu \mathrm{g} / \mathrm{m}^{3}\right)$ map of the highest mean 1 hour for livestock facility with capacity from over 200 to 500 pigs.

Livestock facility with capacity from over 200 to 500 pigs are shown in Figure 5 , the concentration of $\mathrm{H}_{2} \mathrm{~S}, \mathrm{CH}_{3} \mathrm{SH}, \mathrm{NH}_{3}$ are lower than the permitted level according to QCVN 06:2009/BTNMT. The highest simulated results for 1 hour of $\mathrm{H}_{2} \mathrm{~S}, \mathrm{CH}_{3} \mathrm{SH}, \mathrm{NH}_{3}$ respectively reached $7.22 \mu \mathrm{g} / \mathrm{m}^{3}, 4.16 \mu \mathrm{g} / \mathrm{m}^{3}$ and $38.7 \mu \mathrm{g} / \mathrm{m}^{3}$. 


\subsubsection{Livestock facility with capacity from over 500 to 1,000 pigs}

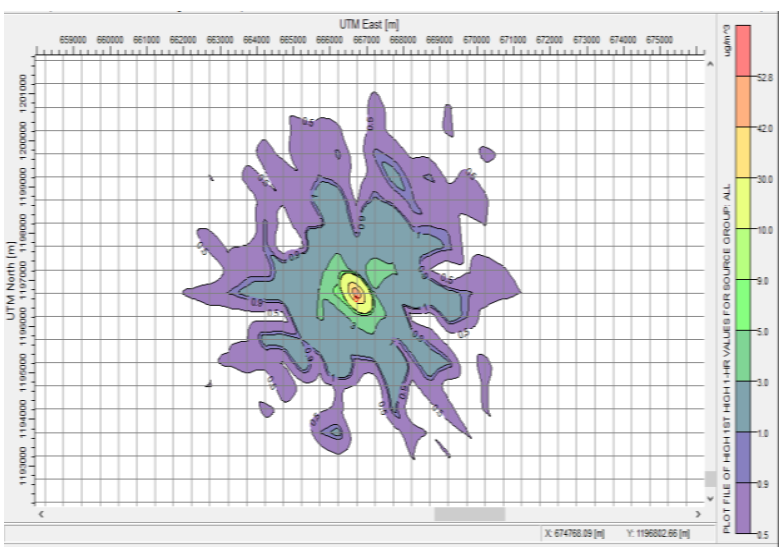

(I)

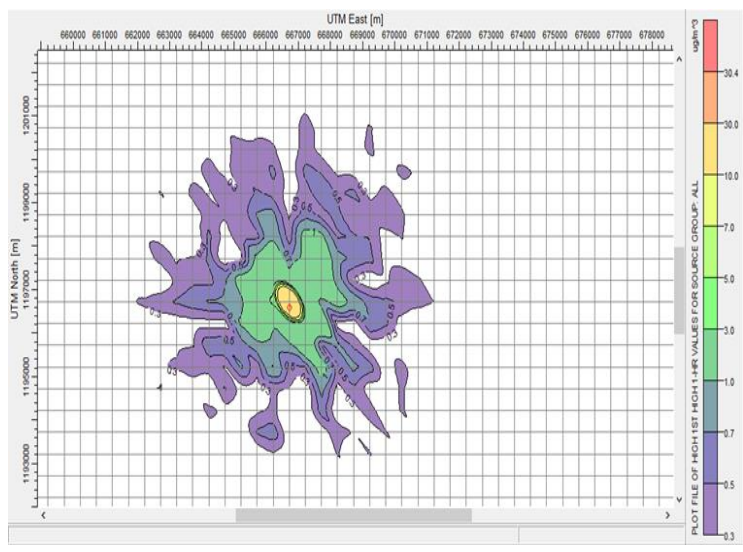

(II)

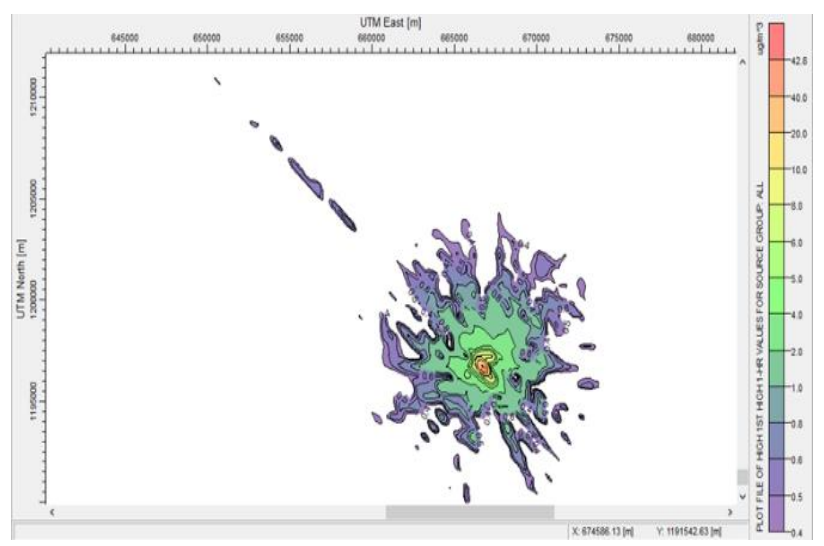

(III)

Figure 6: Simulated result for $\mathrm{H}_{2} \mathrm{~S}$ (I), $\mathrm{CH}_{3} \mathrm{SH}$ (II), $\mathrm{NH}_{3}$ (III) concentrations $\left(\mu \mathrm{g} / \mathrm{m}^{3}\right)$ map of the highest mean 1 hour for livestock facility with capacity from over 500 to 1,000 pigs.

Odor simulated results for livestock facility with capacity from over 500 to 1,000 pigs are shown in Figure 6 . The highest values for 1 hour of $\mathrm{CH}_{3} \mathrm{SH}, \mathrm{NH}_{3}$ respectively reached $30.4 \mu \mathrm{g} / \mathrm{m}^{3}$ và $42.8 \mu \mathrm{g} / \mathrm{m}^{3}$, these results are lower than the permitted level according to QCVN 06:2009/BTNMT. However, the highest average hourly $\mathrm{H}_{2} \mathrm{~S}$ simulation result reached $52.8 \mu \mathrm{g} / \mathrm{m}^{3}, 1.3$ times higher than the permitted level according to QCVN 06:2009/BTNMT (standard allowable 1 hour is $42 \mu \mathrm{g} / \mathrm{m}^{3}$ ).

Odor simulated results for livestock facility with capacity from over 1,000 to 10,000 pigs are shown in Figure 7. The highest values for 1 hour of $\mathrm{H}_{2} \mathrm{~S}, \mathrm{CH}_{3} \mathrm{SH}, \mathrm{NH}_{3}$ reached $98.98 \mu \mathrm{g} / \mathrm{m}^{3}, 57.1 \mu \mathrm{g} / \mathrm{m}^{3}$ and $531 \mu \mathrm{g} / \mathrm{m}^{3}$, respectively. These results are higher than the permitted level according to QCVN 06:2009/BTNMT, 2.4 times $\left(\mathrm{H}_{2} \mathrm{~S}\right), 1.1$ times $\left(\mathrm{CH}_{3} \mathrm{SH}\right), 2.6$ times $\left(\mathrm{NH}_{3}\right)$ (standard allowable 1 hour for $\mathrm{H}_{2} \mathrm{~S}, \mathrm{CH}_{3} \mathrm{SH}, \mathrm{NH}_{3}$ are 42,50 and $200 \mu \mathrm{g} / \mathrm{m}^{3}$ ).

\subsubsection{Livestock facility with capacity over 10,000 pigs}

Odor simulated results for livestock facility with capacity over 10.000 pigs are shown in Figure 8 . The highest value for 1 hour of $\mathrm{CH}_{3} \mathrm{SH}$ reached $30.8 \mu \mathrm{g} / \mathrm{m}^{3}$, this result is lower than the permitted level according to QCVN 06:2009/BTNMT. However, the highest average hourly $\mathrm{H}_{2} \mathrm{~S}, \mathrm{NH}_{3}$ simulated results reached $106 \mu \mathrm{g} / \mathrm{m}^{3}$ and $287 \mu \mathrm{g} / \mathrm{m}^{3}$, higher than the permitted level according to QCVN 06:2009/BTNMT, 2.5 times $\left(\mathrm{H}_{2} \mathrm{~S}\right)$, 1.4 times $\left(\mathrm{NH}_{3}\right)$ higher than the permitted level according to QCVN 06:2009/BTNMT (standard allowable 1 hour for $\mathrm{H}_{2} \mathrm{~S}, \mathrm{NH}_{3}$ are 42 and $200 \mu \mathrm{g} / \mathrm{m}^{3}$ ). 
From simulated results for $\mathrm{H}_{2} \mathrm{~S}, \mathrm{CH}_{3} \mathrm{SH}$, and $\mathrm{NH}_{3}$ for each livestock facility at Section 3.3. Odor isolation distance will be calculated as follow QCVN 06:2009/BTNMT and decision No 3733/2002/QĐ-BYT, odor isolation distance is suitable for each livestock facility were listed as Table 5. With livestock facilty capacity from 50 to 200 pigs and over 200 to 500 pigs, the simulated results show that $\mathrm{H}_{2} \mathrm{~S}, \mathrm{CH}_{3} \mathrm{SH}, \mathrm{NH}_{3}$ concentrations were lower than the permitted level according to QCVN 06:2009/BTNMT. With livestock facility capacity over 500 to 1,000 pigs, only simulated concentration of $\mathrm{H}_{2} \mathrm{~S}$ was higher than the permitted level according to QCVN 06:2009/BTNMT, so that, the odor isolation distance was calculated for this livestock facility was at least $230 \mathrm{~m}$. With livestock facility capacity over 1,000 to 10,000 pigs, all the simulated results of $\mathrm{H}_{2} \mathrm{~S}, \mathrm{CH}_{3} \mathrm{SH}, \mathrm{NH}_{3}$ were higher than the permitted level according to QCVN 06:2009/BTNMT, and the isolation distance of $\mathrm{H}_{2} \mathrm{~S}, \mathrm{CH}_{3} \mathrm{SH}, \mathrm{NH}_{3}$ were 600,650 and $510 \mathrm{~m}$, respectively. Therefore, the odor isolation distance for livestock facility capacity over 1,000 to 10,000 pigs was at least $650 \mathrm{~m}$. With livestock facility capacity over 10,000 pigs, the simulated results show that $\mathrm{H}_{2} \mathrm{~S}, \mathrm{NH}_{3}$ concentrations were higher than the permitted level according to QCVN 06:2009/BTNMT, and the isolation distance of $\mathrm{H}_{2} \mathrm{~S}, \mathrm{NH}_{3}$ were calculated are 650 and $400 \mathrm{~m}$, respectively. Hence, the odor isolation distance for livestock facility capacity over 10,000 pigs was at least $650 \mathrm{~m}$.

\subsubsection{Livestock facility with capacity over 1,000 to 10,000 pigs}

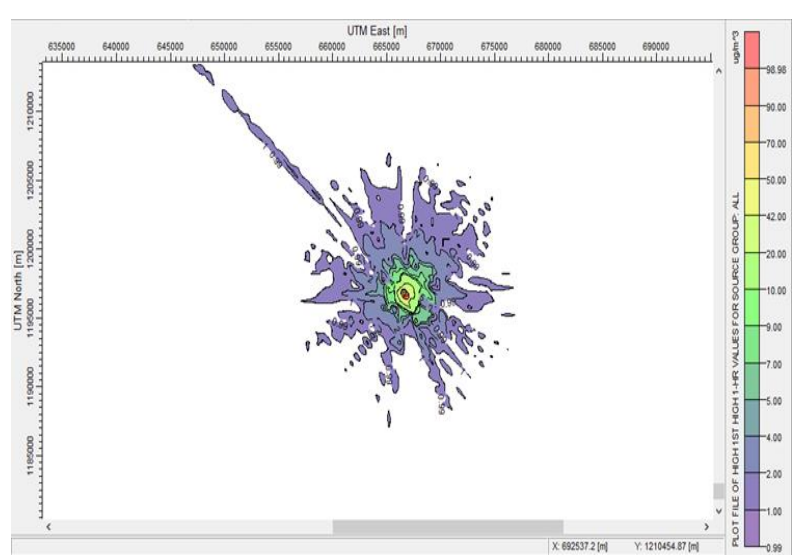

(I)

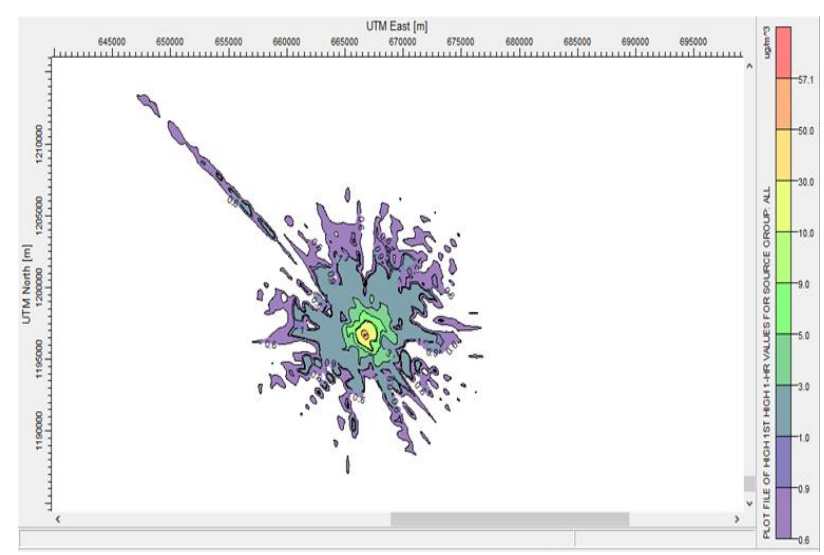

(II)

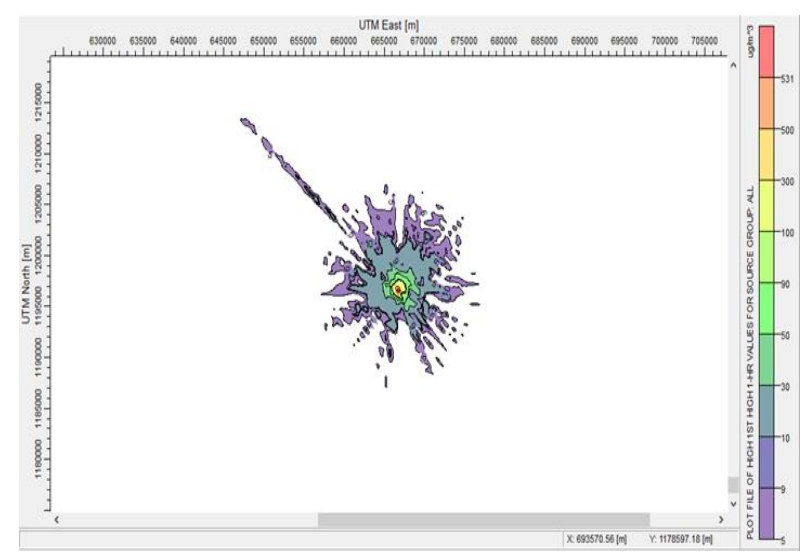

(III)

Figure 7: Simulated result for $\mathrm{H}_{2} \mathrm{~S}(\mathrm{I}), \mathrm{CH}_{3} \mathrm{SH}$ (II), $\mathrm{NH}_{3}$ (III) concentrations $\left(\mu \mathrm{g} / \mathrm{m}^{3}\right)$ map of the highest mean 1 hour for livestock facility with capacity from over 1,000 to 10,000 pigs. 


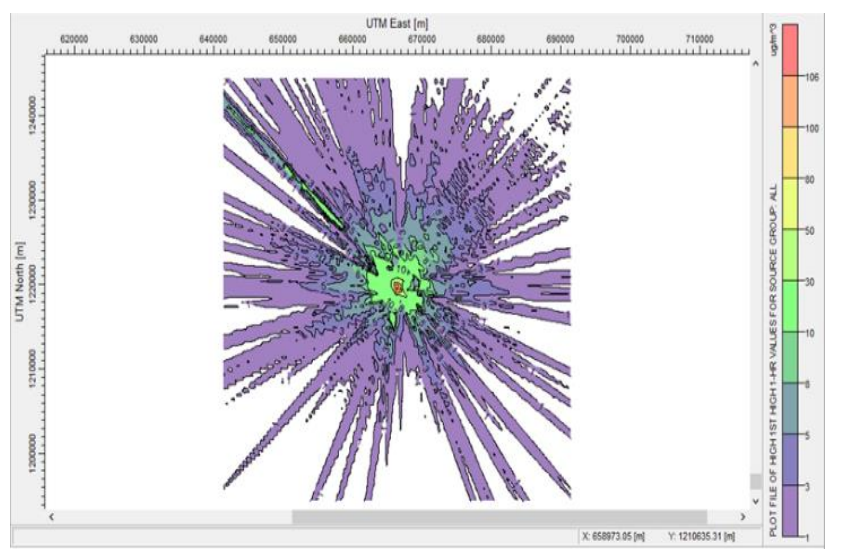

(I)

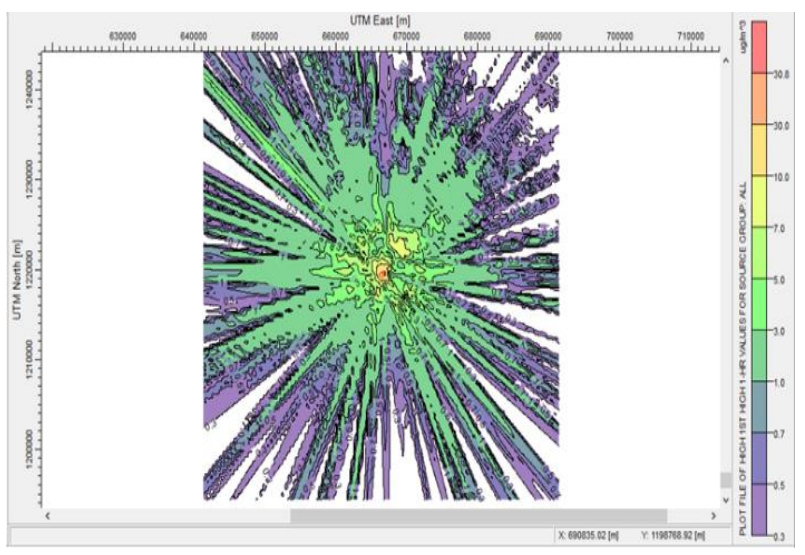

(II)

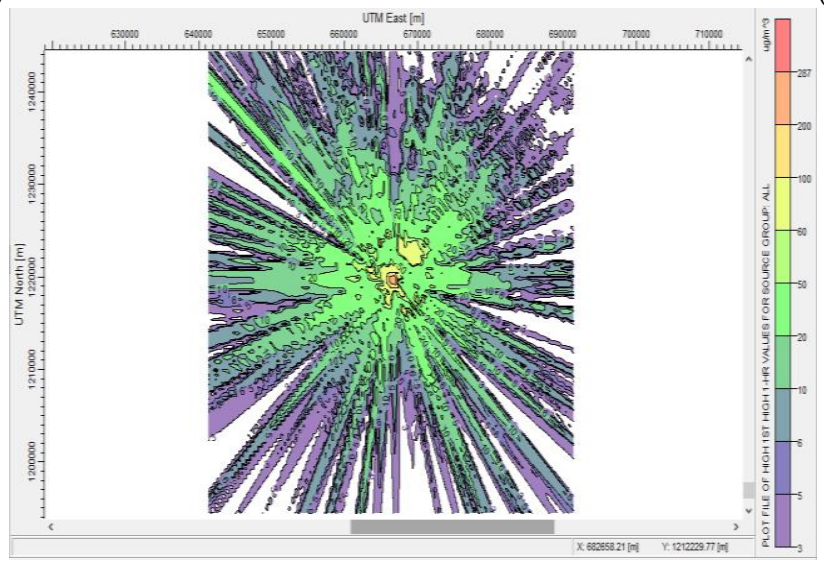

(III)

Figure 8. Simulated result for $\mathrm{H}_{2} \mathrm{~S}$ (I), $\mathrm{CH}_{3} \mathrm{SH}$ (II), $\mathrm{NH}_{3}$ (III) concentrations $\left(\mu \mathrm{g} / \mathrm{m}^{3}\right)$ map of the highest mean 1 hour for livestock facility with capacity from over 10,000 pigs.

\subsection{Developing a process to calculate the odor isolation safe distance}

\subsubsection{The odor isolation safe distance for livestock facilities}

The odor safe distances were calculated based on the National technical regulation on hazardous substances in ambient air QCVN 06:2009/BTNMT. According decision No 3733/2002/Qפ-BYT has defined the hygienic distance is the minimum distance calculated from the source of emission in the house, factory or technological line to the residential area. So that, if simulated results exceeded, the permissible standard, the isolation distances from livestock facilities to the surrounding area were measured from the emission sources to boundary between the exceeding and standard area, as follow Figure 9.

\subsection{Procedure for calculating odor isolation distance for livestock facility}

From simulation and calculation results of the odor isolation distance between livestock facilities and surrounding residential areas applied to Ho Chi Minh City, this study developed a procedure to calculate the odor isolation distance for each livestock facility as shown in Figure 10. This procedure may be applied to other livestock facilities in Vietnam. 


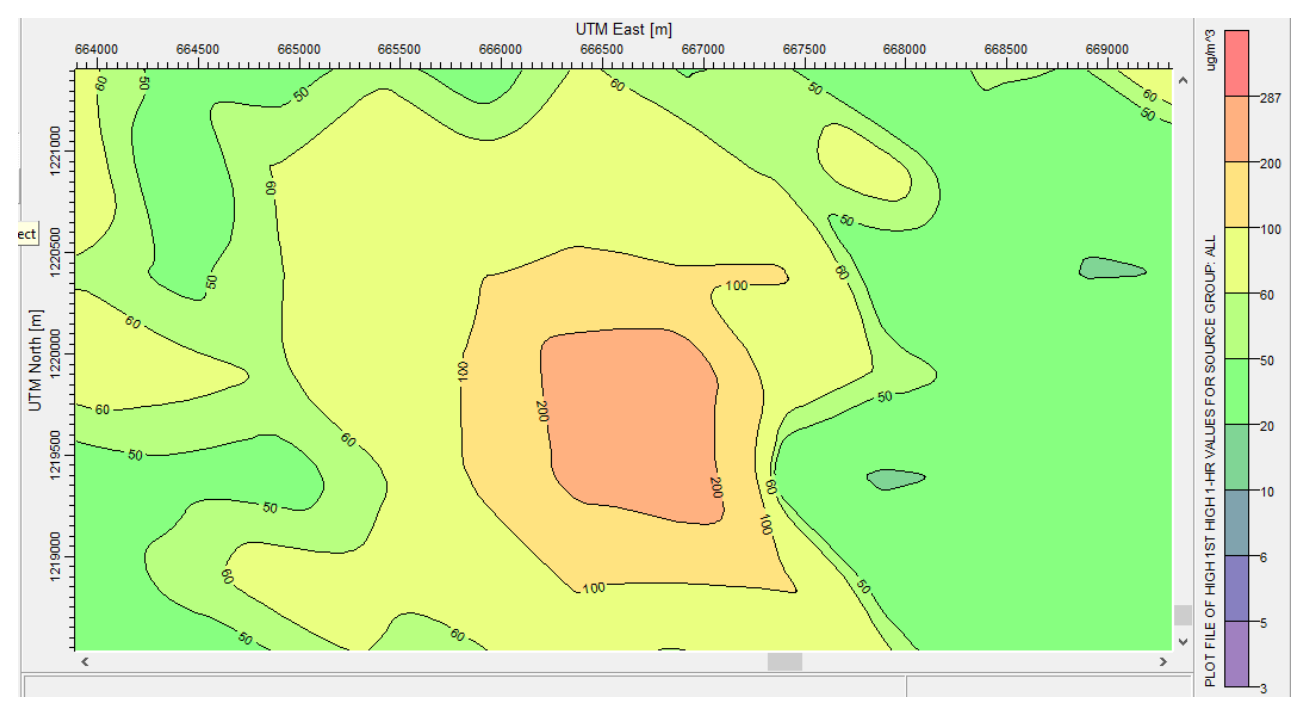

Figure 9: Calculated result of $\mathrm{NH}_{3}$ isolation safe distance for livestock facility with capacity from over 10,000 pigs.

Table 5: Odor isolation distance is suitable for each livestock facility.

\begin{tabular}{|c|c|c|c|c|c|c|}
\hline Livestock facility & Parameter & $\begin{array}{l}\text { Average } \\
\text { time }\end{array}$ & Value $\left(\mu \mathrm{g} / \mathrm{m}^{3}\right)$ & $\begin{array}{c}\text { QCVN } \\
06: 2009 / B T N M T\end{array}$ & $\begin{array}{l}\text { Minimum } \\
\text { odor } \\
\text { isolation } \\
\text { distance }\end{array}$ & $\begin{array}{l}\text { Matching } \\
\text { isolation } \\
\text { distance }\end{array}$ \\
\hline \multirow{3}{*}{ From 50 to 200 pigs } & $\mathrm{NH}_{3}$ & $1 \mathrm{~h}$ & $0.7-65.6$ & Passed & & \\
\hline & $\mathrm{H}_{2} \mathrm{~S}$ & $1 \mathrm{~h}$ & $0.1-12.2$ & Passed & & \\
\hline & $\mathrm{CH}_{3} \mathrm{SH}$ & $1 \mathrm{~h}$ & $0.07-7.04$ & Passed & & \\
\hline \multirow{3}{*}{$\begin{array}{l}\text { Over } 200 \text { to } 500 \\
\text { pigs }\end{array}$} & $\mathrm{NH}_{3}$ & $1 \mathrm{~h}$ & $0.4-38.7$ & Passed & & \\
\hline & $\mathrm{H}_{2} \mathrm{~S}$ & $1 \mathrm{~h}$ & $0.07-7.22$ & Passed & & \\
\hline & $\mathrm{CH}_{3} \mathrm{SH}$ & $1 \mathrm{~h}$ & $0.04-4.16$ & Passed & & \\
\hline \multirow{3}{*}{$\begin{array}{l}\text { Over } 500 \text { to } 1,000 \\
\text { pigs }\end{array}$} & $\mathrm{NH}_{3}$ & $1 \mathrm{~h}$ & $0.4-42.8$ & Passed & & \\
\hline & $\mathrm{H}_{2} \mathrm{~S}$ & $1 \mathrm{~h}$ & $0.5-52.8$ & Exceeds standard & $230 m$ & $230 \mathrm{~m}$ \\
\hline & $\mathrm{CH}_{3} \mathrm{SH}$ & $1 \mathrm{~h}$ & $0.04-4.16$ & Passed & & \\
\hline \multirow{3}{*}{$\begin{array}{l}\text { Over } \quad 1,000 \\
10,000 \text { pigs }\end{array}$} & $\mathrm{NH}_{3}$ & $1 \mathrm{~h}$ & $5.0-531.0$ & Exceeds standard & 650 & \\
\hline & $\mathrm{H}_{2} \mathrm{~S}$ & $1 \mathrm{~h}$ & $0.99-98.98$ & Exceeds standard & $600 \mathrm{~m}$ & $650 \mathrm{~m}$ \\
\hline & $\mathrm{CH}_{3} \mathrm{SH}$ & $1 \mathrm{~h}$ & $0.6-57.1$ & Exceeds standard & $510 m$ & \\
\hline \multirow{3}{*}{ Over 10,000 pigs } & $\mathrm{NH}_{3}$ & $1 \mathrm{~h}$ & $3.0-287.0$ & Exceeds standard & $400 m$ & \\
\hline & $\mathrm{H}_{2} \mathrm{~S}$ & $1 \mathrm{~h}$ & $1.0-106.0$ & Exceeds standard & $650 \mathrm{~m}$ & $650 \mathrm{~m}$ \\
\hline & $\mathrm{CH}_{3} \mathrm{SH}$ & $1 \mathrm{~h}$ & $0.3-30.8$ & Passed & & \\
\hline
\end{tabular}


Step 1: Site survey to calculate odor emission.

+ Livestock facilities (long $\times$ wide);

+ Coordinates;

+ Number of pigs each livestock facility;

+ Waste treatment:

+ Distance from livestock facility to residential area;

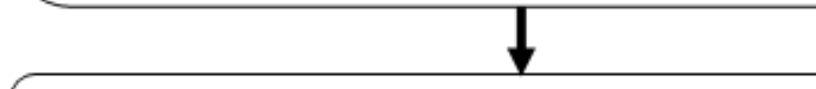

Step 2: Calculate emission for each livestock facility base on emissons factor from Erreur! Source du renvoi introuvable.

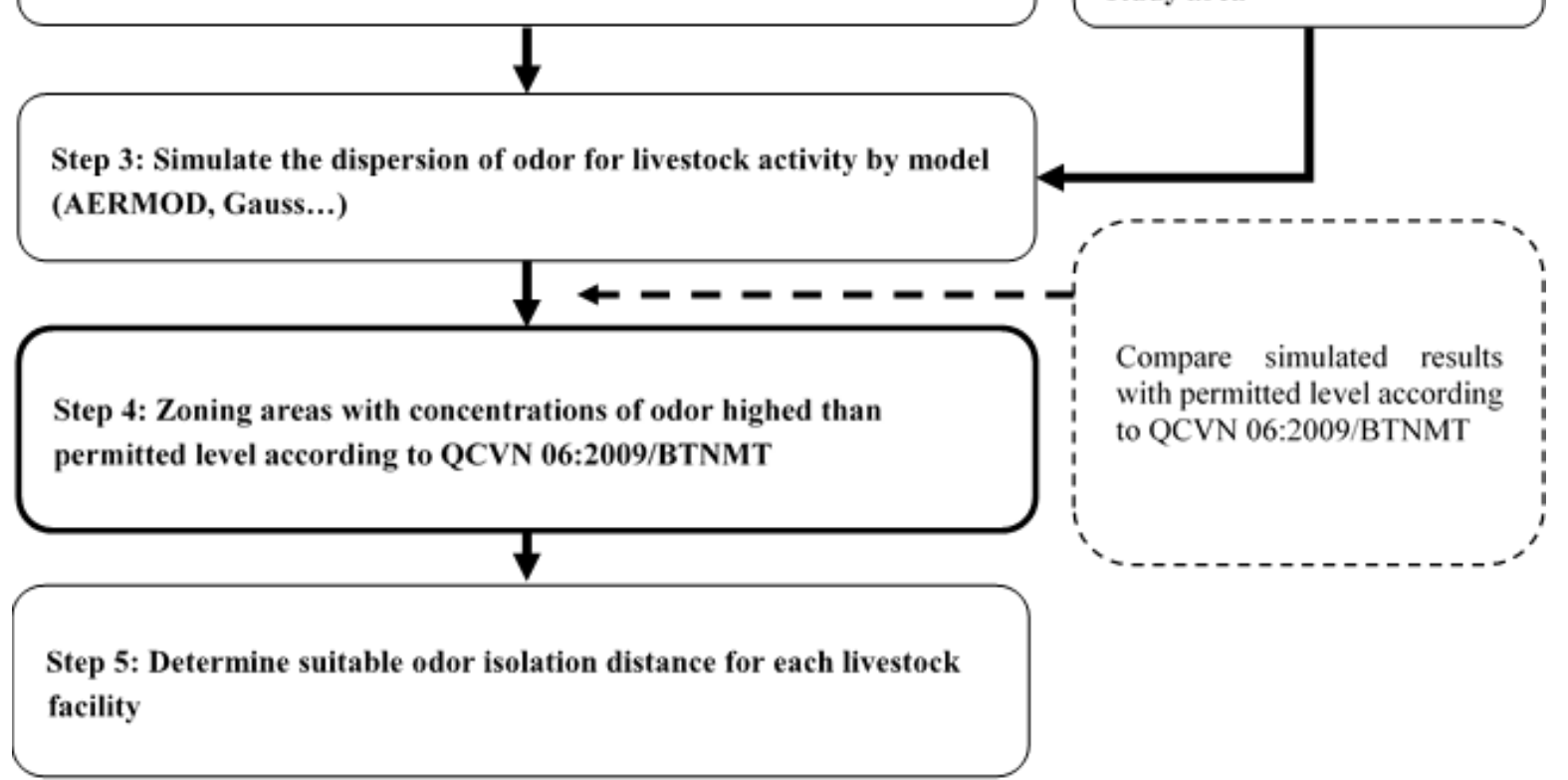

Figure 10: Procedure for calculating odor isolation distance for livestock facilities.

\section{CONCLUSIONS AND RECOMMENDATIONS}

This study calculated odor emission and simulated dispersion of odor by TAPM-AERMOD system models. After that, the simulated results were used to calculate odor isolation distance between livestock facility and surrounding area. Simulated results for $\mathrm{H}_{2} \mathrm{~S}, \mathrm{CH}_{3} \mathrm{SH}$, $\mathrm{NH}_{3}$ show that: The livestock facilities capacity from 50 to 200 pigs and over 200 to 500 pigs lower than permitted level according to QCVN 06:2009/BTNMT about hazardous substances in ambient air. With livestock facility capacity over 500 to 1,000 pigs, the simulated results show that $\mathrm{H}_{2} \mathrm{~S}$ concertration is higher than than the permitted level according to QCVN 06:2009/BTNMT, so that, the odor isolation distance was calculated for this livestock facility is at least $230 \mathrm{~m}$. The livestock facility capacity over 1,000 to 10,000 pigs, the simulated results show that $\mathrm{H}_{2} \mathrm{~S}, \mathrm{CH}_{3} \mathrm{SH}, \mathrm{NH}_{3}$ concertrations are higher than the permitted level according to QCVN 06:2009/BTNMT and the odor isolation distance for livestock facility capacity over 1,000 to 10,000 pigs is at least $650 \mathrm{~m}$. With livestock facility capacity over 10,000 pigs, the simulated results show that $\mathrm{H}_{2} \mathrm{~S}, \mathrm{NH}_{3}$ concertrations are higher than the permitted level according to $\mathrm{QCVN}$ $06: 2009 / B T N M T$ and the odor isolation distance for livestock facility capacity over 1,000 pis is at least $650 \mathrm{~m}$. From the above reseatch 
results indicate that, the odor isolation distance depends not only on number of pig per livestock facility but also on the livestock facility area and topographic conditions of the study area. So that, a procedure to calculate the distance of odor isolation has also developed. This procedure can also be used to apply to other provinces and cities.

\section{ACKNOWLEDGMENTS}

This research is funded by Vietnam National University Ho Chi Minh City (VNU-HCM) under grant number C2019-24-05. The authors thank Vietnam National University in Ho Chi Minh for providing the fund.

\section{REFERENCES}

Canh, T. T. (2010). Control of environmental pollution and economical use of waste in livestock production. Scientific and Technical book.

Committee, H. P. s. (2019). "Ho Chi Minh City continues to assert as the national economic leader in 2018." Nouvelles infographiques nationales.

Cope, M., Lee, S. (2009). Chemical Transport Model User Manual. The Centre for Australian Weather and Climate Research.

GeneralStatisticsOffice (2019). Statistics of pig households 2019. https://channuoivietnam.com/thong-ke-chan-nuoi/tk-chan-nuoi/?cp=1.

Ho Minh Dung, H. Q. B., Le Viet Thang (2019). Evaluate of air pollution dispersion and propose planing scenerios to reduce air pollution for livestock activities in Tan Thanh district, Ba Ria - Vung Tau province. Science \& Technology Development Journal: Science Of The Earth \& Environment 2(2).

Ho Quoc Bang, H. M. D., Nguyen Thoai Tam (2016). Air quality studies in Hoang Dieu Port, Can Tho City. Tạp chí Phát triển Khoa học và Công nghệ, ĐHQG Tp.HCM M2-2016.

Hoa, D. T. X. (2017). Emission inventory from livestock activity, a case for Tho Vinh, Kim Dong, Hung Yen. University of Natural Science.

Hurley, P. (2008). The Air Pollution Model (TAPM) Version 4. Part 1: Technical description. CSIRO Marine and Atmospheric Research: 25.

Kenneth D. Casey, J. R. B. (2006). Air quality and emissions from livestock and poultry production/waste management systems. Animal Agriculture and the Environment: National Center for Manure and Animal Waste Management White Papers: 1-40.

Ki Youn Kim, H. J. K. (2007). Sulfuric odorous compounds emitted from pig-feeding operations. Atmospheric Environment 41(23): 48114818.

Lakesenvironmental (2013). AERMOD model information. http://www.weblakes.com.

Truong Thanh Canh, P. D. X. V. (1998). The situation of environmental pollution in the livestock activities, solutions to limit environmental pollution and improve the efficiency of fertilizer. Dong Nai Environment science and technology journal.

Wen Xu, K. Z., XuejunLiu, LingminMeng (2014). Atmospheric NH3 dynamics at a typical pig farm in China and their Implications. Atmospheric Pollution Research 5(3): 455-463. 